\title{
UTILIZAÇÃO DE OZÔNIO COMO SANITIZANTE DE FRUTAS: EFEITO SOB AS ANTOCIANINAS TOTAIS DA AMORA-PRETA
}

\author{
A. C. JACQUES ${ }^{1}$, F. M. OLIVEIRA ${ }^{1}$, R. C. ZAMBIAZI ${ }^{2}$, E. A. GANDRA ${ }^{2}$ \\ ${ }^{1}$ Universidade Federal do Pampa \\ ${ }^{2}$ Universidade Federal de Pelotas \\ E-mail para contato: fer.moroli@gmail.com
}

\begin{abstract}
RESUMO - A presença de microrganismos em frutas pode levar a toxinfecções alimentares, em busca de agentes sanitizantes de alimentos não geradores de resíduos, surgiu a ozonização. No Brasil, não existe legislação específica que oriente aplicações em alimentos e há poucos estudos sobre os efeitos nos componentes dos mesmos, como nos compostos antociânicos, responsáveis pela coloração de grande quantidade de frutas, como a amora-preta, e que apresentam benefícios a saúde como ação antioxidante. Em face do exposto, o presente trabalho teve por objetivo verificar o efeito do ozônio sob as antocianinas presentes na amora-preta na sanitização. Foram realizadas análises microbiológicas para bolores e leveduras, coliformes totais, termotolerantes e antocianinas totais. A utilização do ozônio como sanitizante apresentou bons resultados sem alteração nos compostos antociânicos presentes independente da concentração utilizada
\end{abstract}

\section{INTRODUÇÃO}

A amora-preta (blackberry) pertence ao gênero Rubus que contém, aproximadamente, 740 espécies divididas segundo alguns autores, em 12 a 15 subgêneros (Jennings, 1988, apud Daubeny, 1996). As frutas, principalmente as que apresentam a coloração vermelha e/ou azul, como a amora-preta, são as mais importantes fontes de compostos antociânicos em dietas alimentares, apresentando uma gama de efeitos biológicos, incluindo ação antioxidante, antimicrobiana, antiinflamatória e vasodilatadora (Degáspari; Waszczynsky, 2004). As frutas e hortaliças são potenciais veiculadores de microrganismos que podem estar associados à toxinfecções alimentares e, conseqüentemente, a doenças transmitidas por alimentos (DTA). Nos últimos anos tem existido certa preocupação quanto ao uso do hipoclorito e dos demais sais de cloro por serem considerados precursores na formação de cloraminas orgânicas, as quais são prejudiciais à saúde devido ao seu alto potencial carcinogênico, com isto a preocupação com pesquisas de novos agentes sanitizantes que não gerem resíduos deve ser acelerada, surgindo a opção da utilização de ozônio como santizante de alimentos. 
A ozonização passou a ser utilizada no Brasil como alternativa aos métodos convencionais de pré-cloração e pré-aeração no tratamento de águas superficiais a partir de 1983 (Lapolli et al., 2003). Na área de alimentos, poucas pesquisas têm sido realizadas no Brasil e ainda não existe legislação específica que oriente aplicações nesta área.

Em face do exposto, o objetivo deste trabalho foi de avaliar a eficiência da sanitização com ozônio em diferentes concentrações e determinar a influência da sanitização sob os compostos antociânicos totais da amora-preta cv. Tupy.

\section{MATERIAL E METODOS}

\subsection{Ozonização}

A água ozonizada foi gerada borbulhando-se o gás ozônio em água destilada a $2^{\circ} \mathrm{C}$ por 15 minutos $(1,75 \mathrm{ppm}), 30$ minutos $(3 \mathrm{ppm})$ e $1 \mathrm{~h}(4 \mathrm{ppm})$. Para isso foi utilizado um equipamento gerador de ozônio (Trata OZ, modelo TLS 6A) cedido pela empresa OZ Engenharia Ltda. (RS), o qual se fundamenta no efeito corona, ou seja, na geração de ozônio pela descarga elétrica sobre o oxigênio. O residual de ozônio na água foi medido pelo método Padrão do índigo, aceito mundialmente pelo United States Environmental Protection Agency (EPA) e pelo International Ozone Association (IOA), sendo o único método a constar no Standards methods for the examination of water and wastewater (1997).

\subsection{Determinação de bolores e leveduras}

Para contagem de bolores e leveduras, foi utilizado o método de plaqueamento direto em superfície das diluições $10^{-1}, 10^{-2}, 10^{-3}$ e $10^{-4}$ em meio Ágar Batata Dextrose.

\subsection{Determinação do número mais provável $\left(\mathrm{NMP}^{-g^{-1}}\right)$ de coliformes totais e termotolerantes}

Alíquotas de $1 \mathrm{~mL}$ de cada diluição foram inoculadas em séries de três tubos contendo 9 $\mathrm{mL}$ de caldo Lauril Sulfato Triptose (LST), com tubo de Duhran invertido (teste presuntivo). Os tubos foram incubados a $35^{\circ} \mathrm{C}$ por $24-48$ horas. A partir dos tubos com leitura positiva (turvação e formação de gás), foram realizados os testes confirmativos para coliformes totais em caldo Lactose Bile Verde Brilhante (VB) a $35{ }^{\circ} \mathrm{C}$ por $24-48$ horas e coliformes termotolerantes em caldo Escherichia coli (EC) a $45^{\circ} \mathrm{C}$ por 24 horas. 


\subsection{Determinação de $E$. coli}

Para confirmação da presença de E. coli, uma alçada de tubos contendo caldo EC que apresentavam turbidez, com ou sem produção de gás no interior do tubo de Durhan, foi semeada em placas de Petri contendo Ágar Eosina Azul de Metileno (EMB). As placas foram incubadas a $37^{\circ} \mathrm{C}$ por 24 horas.

\subsection{Determinação de Salmonella}

Alíquotas de $1 \mathrm{~mL}$ da cultura pré-enriquecida foi transferidas para dois tubos, contendo cada um $10 \mathrm{~mL}$ de caldo de enriquecimento seletivo, composto pelo caldo Tetrationato - TT e pelo caldo Rappaportt - RV, e incubadas (TT $24 \mathrm{~h} / 37^{\circ} \mathrm{C}$ e RV $24 \mathrm{~h} / 45^{\circ} \mathrm{C}$ ). A partir desses caldos, uma alíquota de cada tubo foi semeada em ágar XLD e outra em ágar HE e incubadas em estufa a $35^{\circ} \mathrm{C}$ por $24 \mathrm{~h}$.

\subsection{Determinação de antocianinas totais}

A determinação de antocianinas totais foi feita utilizando-se etanol acidificado, seguindo método original (Lees e Francis, 1972). O cálculo do conteúdo total de antocianinas foi baseado na Lei de Beer e os resultados foram expressos em mg de cianidina 3-glicosídio por $100 \mathrm{~g}^{-1}$ de amostra.

\section{RESULTADOS E DISCUSSAO}

Tabela 1 - Resultados das análises microbiológicas para bolores e leveduras, coliformes totais das frutas sanitizadas com ozônio

\begin{tabular}{ccc}
\hline $\begin{array}{c}\text { Polpas } \\
\text { Ozônio }\end{array}$ & $\begin{array}{c}\text { Bolores e leveduras } \\
\left(\mathrm{UFC} \cdot \mathrm{g}^{-1}\right)\end{array}$ & $\begin{array}{c}\text { Coliformes totais } \\
\left(\mathrm{NMP} . \mathrm{g}^{-1}\right)\end{array}$ \\
\hline Sem tratamento & $3,75 \times 10^{6}$ & - \\
$1,75 \mathrm{ppm}$ & $5 \times 10^{3}$ & - \\
$3 \mathrm{ppm}$ & $3,73 \times 10^{3}$ & - \\
$4 \mathrm{ppm}$ & $2 \times 10^{2}$ & - \\
Padrão Federal & $5 \times 10^{3 *}$ & $1^{*}$ \\
\hline
\end{tabular}

* Instrução Normativa ${ }^{\circ} 1$ de 07 jan de 2000

** RDC n ${ }^{\circ} 12$, de 02/01/2001 
Tabela 2 - Resultados das análises microbiológicas para termotolerantes e Salmonella das frutas sanitizadas com ozônio

\begin{tabular}{ccc}
\hline $\begin{array}{c}\text { Coliformes termotolerantes } \\
\left(\mathrm{NMP} . \mathrm{g}^{-1}\right)\end{array}$ & $\begin{array}{c}\text { Pesquisa de } \text { E. coli } \\
\text { ausência/presença }\end{array}$ & $\begin{array}{c}\text { Pesquisa de Salmonella } \\
\text { ausência/presença }\end{array}$ \\
\hline- & Ausência & Ausência \\
- & Ausência & Ausência \\
- & Ausência & Ausência \\
- & Ausência & Ausência \\
$10^{2^{* *}}$ & Ausência & Ausência em $25 \mathrm{~g}$ \\
\hline
\end{tabular}

* Instrução Normativa ${ }^{\circ} 1$ de 07 jan de 2000

$* * \mathrm{RDC} \mathrm{n}^{\mathrm{o}} 12$, de $02 / 01 / 2001$

De acordo com a Tabela 1 e 2, observa-se que a sanitização das frutas com ozônio em todas as concentrações utilizadas, foi eficiente para manter os níveis de bolores e leveduras de acordo com o anexo I do Regulamento técnico geral para fixação dos padrões de identidade e qualidade para polpa de fruta da Instrução normativa ${ }^{\circ} 1$ de 07 de janeiro de 2000.

Não foram encontrados dados de sanitização de frutas com ozônio nas concentrações utilizadas neste estudo, sendo que fazendo uma comparação com sanitização a partir de soluções cloradas, alguns autores necessitaram de concentrações bem mais elevadas para manter os níveis no padrão Federal. Antoniolli (2005), utilizou $\mathrm{NaOCl}$, na concentração de $200 \mathrm{mg}^{-1} \mathrm{~L}^{-1}$ para abacaxis com cloro obtendo, nesta concentração, êxito na sanitização.

A presença de fungos verificada nas amostras sem tratamento não parece ser um fato restrito, Nascimento et al. (1999), ao estabelecerem o perfil microbiológico de polpas produzidas e comercializadas na cidade de São Luís - MA, constataram que 100\% das amostras apresentaram contaminação por bolores e leveduras, apresentando contagens entre $1,0 \times 105$ e $1,1 \times$ 108 UFC. ${ }^{-1}$. Segundo Franco e Landgraf (2003), baixas contagens de bolores e leveduras são consideradas normais (não significativas) em alimentos frescos e congelados. No entanto, contagens elevadas representam, além do aspecto deteriorante, que pode levar inclusive à rejeição do produto, um risco à saúde pública devido à possível produção de micotoxinas por algumas espécies de bolores.

A Legislação Brasileira, ANVISA - Resolução RDC-12 (Brasil, 2002), estabelece o limite de 5 x 102 UFC de coliformes fecais por grama, para frutas, produtos de frutas e similares - frescas, in natura, preparadas (descascadas ou selecionadas ou fracionadas), sanitizadas, refrigeradas ou congeladas para consumo direto. $\mathrm{O}$ baixo valor de $\mathrm{pH}$ apresentado pela maioria das frutas pode representar um fator limitante para o crescimento de bactérias patogênicas, mantendo os índices de contaminação bacteriana em níveis baixos. De acordo com Mota (2006), o pH da amora-preta cv. Tupy é de 3,23.

Contaminação por coliformes totais e termotolerantes em maracujá foi encontrada por Leite et al. (2000) e Lima et al. (2001), estando, provavelmente, associada à manipulação 
inadequada durante o processamento da matéria-prima, ou à contaminação de equipamentos, sendo que neste estudo não foram evidenciadas a presença de coliformes totais e termotolerantes em nenhum dos tratamentos realizados. Com relação à Salmonella, não foi observada em nenhuma amostra a presença deste microrganismo nas amostras sanitizadas com ozônio.

Tabela 3 - Resultados de antocianinas totais das frutas sanitizadas com ozônio

\begin{tabular}{cc}
\hline Ozônio & Antocianinas Totais $\left(\mathrm{mg} .100 \mathrm{~g}^{-1}\right)$ \\
\hline $1,75 \mathrm{ppm}$ & $110,9 \pm 2,52^{\mathrm{a}}$ \\
$3 \mathrm{ppm}$ & $109,78 \pm 3,62^{\mathrm{a}}$ \\
$4 \mathrm{ppm}$ & $109,55 \pm 1,82^{\mathrm{a}}$ \\
\hline
\end{tabular}

\pm Desvio padrão; $*$ letras diferentes na mesma coluna indicam diferença significativa ao nível de confiança de $95 \%$

Observou-se na Tabela 3, que com a sanitização com ozônio não houve diferença significativa entre os tratamentos no teor de antocianinas totais, pigmento predominate na amorapreta. Mesmo em baixas concentrações a efetividade da sanitização é evidenciada e poucas perdas são oferecidas aos compostos analisados. Não foram encontrados dados deste efeito em outros trabalhos, salientando a importância deste estudo.

\section{CONCLUSÃO}

As frutas sanitizadas com ozônio, apresentaram bons resultados sem alteração nos compostos antociânicos presentes independente da concentração utilizada. $O$ mesmo foi observado para a sanitização, mostrando-se eficiente em todas as concentrações, sendo então o ozônio uma opção viável para sanitização de frutas, sem geração de resíduos nem compostos tóxicos.

\section{REFERÊNCIAS}

ANDRADE, N. J.; MARTYN, M. E. L. Limpeza e sanitização na indústria de alimentos: Viçosa, Universidade Federal de Viçosa,. 1996. 39p. no. 142.

ANTONIOLLI , L. R. et al. Efeito do hipoclorito de sódio sobre a microbiota de abacaxi „pérola ${ }^{\text {ee }}$ minimamente processado. Rev. Bras. Frutic., Jaboticabal - SP, v. 27, n. 1, p. 157-160, Abril 2005. 
BANWART, G. J. Basic food microbiology. 2. ed. New York: Van Nostrand Reinhold, 1989. $774 \mathrm{p}$.

BRASIL. MINISTÉRIO DA AGRICULTURA DO ABASTECIMENTO. Instrução Normativa $\mathrm{n}^{\circ}$ 01/00, de 07/01/00. Regulamento técnico geral para fixação dos padrões de identidade e qualidade para polpa de fruta. Diário Oficial da República Federativa do Brasil, Brasília, DF, 10 jan. 2000, Seção I, p.54-58.

BRUNINI, M. A. et al. Avaliação das alterações em polpa de manga "Tommy-Atkins" congeladas. Revista Brasileira de Fruticultura, v. 24, n. 3, p. 651-653, 2002.

DAUBENY, H.A. Brambles. Fruit Breeding. New York: John Wiley \& Sons, 1996. p.109-190.

DEGÁSPARI, C.H.; WASZCZYNSKYJ, N. Propriedades antioxidantes de compostos fenólicos. Visão Acadêmica, v.5, n.1, p.33-40, 2004.

FILHO, S.S.F.; SAKAGUTTI, M.I comportamento cinético do cloro livre em meio aquoso e formação de subprodutos da desinfecção Eng. sanit. ambient. Vol.13 - No 2 - abr/jun 2008, 198206.

FRANCO, B. D. G.; LANDGRAF, M. Microbiologia de alimentos. 2 ed. São Paulo: Editora Atheneu, 2003.

LAPOLLI, F. R. et al. Desinfecção de efluentes sanitários por meio da ozonização. In. GONÇALVES, R. F. (Coord.). Desinfecção de efluentes sanitários, remoção de organismos patógenos e substâncias nocivas: aplicação para fins produtivos como agricultura, aqüicultura e hidropônica. Vitória: PROSAB, 2003. p. 169-208.

LEES, D. H.; FRANCIS, F. J.; Hortscience 1972, 7, 83.

LEITE, C. C. et al. Avaliação Microbiológica de polpas congeladas de frutas produzidas no Estado da Bahia. Higiene Alimentar, v. 11, n. 78-79, p. 69-73, 2000.

LIMA, J. R. et al. Avaliação de popas de frutas congeladas comercializadas no estado do Ceará através de indicadores microbiológicos. Higiene Alimentar, v.15, n.88, p. 62-66, 2001

NASCIMENTO, A. R. et al. Perfil microbiológico de polpas de acerola (Malpighia glabal) e abacaxi (Ananas comosus), produzidas e comercializadas na ilha de São Luís, MA. Higiene Alimentar, v. 13, n. 62, p. 44-47, 1999.

FILHO, SIDNEY SECKLER FERREIRA; SAKAGUTI, MARIANE Eng. sanit. ambient.; V.13 - No 2 - abr/jun 2008, 198-206. 
SHAMI, N.J.I.E.; MOREIRA, E.A.M. Licopeno como agente antioxidante. Rev. Nutrição, v.17, n.2, p.227-236, 2004. 